\title{
PROJEKT INTERAKTYWNEJ MAPY STAREGO CMENTARZA W LODZI JAKO ELEMENT EDUKACJI I PROMOCJI
}

\begin{abstract}
Zarys treści: Stary Cmentarz w Łodzi jest jedną z nielicznych nekropolii, na której pochowano wyznawców trzech wyznań chrześcijańskich: katolików, protestantów i prawosławnych. Jest on niewątpliwą atrakcją turystyczną miasta, a jej zwiedzanie może mieć przemyślany charakter, np. według wybranych kryteriów lub losowy w postaci spaceru. Osoby wybierające się na ten zabytkowy cmentarz, mogą mieć pewne preferencje co do jego zwiedzania w ciągu jednego dnia. Na cmentarzu pochowano wiele znanych osobistości: nauki, kultury, samorządu miasta, żołnierzy, lekarzy, społeczników i innych. Dzięki zebranym informacjom przestrzennym (lokalizacja nagrobka) oraz aprzestrzennym (biografia, fotografie) można wykorzystać możliwości jakie dają Systemy Informacji Geograficznej do wspomagania decyzji turystów. Artykuł przedstawia proces powstawania aplikacji stworzonej wspólnie przez miłośników Starego Cmentarza w Łodzi, pracowników Muzeum Miasta Łodzi oraz specjalistów geoinformacji, którzy postanowili pomóc odwiedzającym Stary Cmentarz w Łodzi. Mogą oni wybrać nagrobki według osobistych preferencji i zaplanować trasę zwiedzania, a także zapoznać się z biogramami i fotografiami postaci, które zostały pochowane na tym cmentarzu. Ma ona walor edukacyjny i promocji miasta.
\end{abstract}

Słowa kluczowe: mapa interaktywna, Stary Cmentarz, Łódź, geoinformacja, dziedzictwo kulturowe, GIS.

\section{Wprowadzenie}

Systemy Informacji Geograficznej (ang. GIS) są od wielu lat wykorzystywane do popularyzacji dziedzictwa kulturowego (Jażdżewska 2010b), przede wszystkim w celach edukacyjnych, turystycznych, administracyjnych, naukowych i innych. Obydwa te pojęcia mają przynajmniej jedną wspólną cechę, a mianowicie odnoszą się do konkretnej przestrzeni geograficznej. „Dziedzictwo kulturowe to obiekt, 
idea powstała w konkretnej rzeczywistości, w określonych warunkach, w oparciu o zasady historyczne, warunkujące rozwiązania architektoniczne i urbanistyczne. Dziedzictwo kulturowe powinno zatem reprezentować w historii wszystkie grupy społeczne, nawet te występujące w społeczeństwie marginalnie. Dopiero wtedy będzie ono stanowiło ważny element dla rozwoju świadomości i znajomości historii, a także podstaw dla formułowania pojęcia świadomości narodowej. Dlatego żadne zjawisko nie może być wybrane i mieć znaczenia dla dziedzictwa kulturowego, o ile nie jest wpisane w szerszy kontekst opowiadania historycznego" (Lorenc-Karczewska, Witkowski 2002: 125). O dziedzictwie kulturowym województwa łódzkiego pisał M. Kulesza (2003) i wskazywał on na jego wielowyznaniowe cechy. Nagrobki ważnych postaci - często zabytkowe - są więc elementem tego dziedzictwa. Z kolei Systemy Informacji Geograficznej, według J. Gaździckiego (2001), są związane z pozyskiwaniem, gromadzeniem, weryfikacją, analizowaniem, transferem i udostępnianiem danych przestrzennych; w szerokim rozumieniu obejmują metody, środki techniczne - sprzęt i oprogramowanie, bazę danych przestrzennych, organizację, zasoby oraz ludzi zainteresowanych jego funkcjonowaniem. W zakresie badań naukowych oraz popularyzacji dziedzictwa kulturowego Systemy Informacji Geograficznej mogą mieć wpływ na poszczególne etapy badań, jak i na ich aplikacyjny charakter:

1. Pozyskiwanie danych przestrzennych o zabytkach z różnych źródeł;

2. Odpowiednie przechowywanie danych, ich dokumentacja w bazie danych;

3. Integracja danych $w$ jeden system;

4. Wizualizacja danych;

5. Udostępnianie danych, ich popularyzacja (np. książki, mapy, mapy interaktywne etc.);

6. Badania naukowe;

7. Wspomaganie decyzji (finansowanie, zagospodarowanie, ochrona etc.);

8. Monitoring (stanu wiedzy o zabytkach, prac konserwatorskich etc.);

9. Bieżąca aktualizacja informacji o zabytkach.

Podstawy zastosowania GIS w badaniach historycznych, w tym również dziedzictwa kulturowego, odnajdziemy w publikacji A place in history: A guide to using GIS in historical research (Gregory 2003), w której oprócz kwestii teoretycznych związanych z Systemami Informacji Geograficznej, przedstawiono kilka przykładów analiz i i map interaktywnych ${ }^{2}$. Wiele propozycji na wykorzystanie GIS w naukach humanistycznych przedstawiono w czasopiśmie „International Journal of Humanities and Arts Computing" (2009), m.in. w artykule pod znamiennym tytułem What can GIS offer history? Autorka zwraca uwagę na amatorów, miłośników historii, których obserwacje mogą być znacznie większe niż

\footnotetext{
${ }^{1}$ Przedstawiające umieralność niemowląt w Anglii i Walii, lata 90. XIX wieku.

${ }^{2}$ http://www.visionofbritain.org.uk/.
} 
te pozyskane przez pojedynczego naukowca. Może to spowodować powstanie ogromnej ilości nowych dowodów i artefaktów, z którymi naukowcy zajmujący się historią będą mogli pracować, a GIS będzie niezbędny do ich lokalizacji $\mathrm{i}$ archiwizacji, a w kolejnym etapie badań do analiz. GIS zapewnia nie tylko nową ścieżkę dla stypendiów historycznych, ale wkrótce stanie się niezbędnym narzędziem dla historyków (Kemp 2009).

GIS do badań naukowych dziedzictwa kulturowego wykorzystywano w różnych aspektach: jego charakterystyki przestrzennej (Lechowski 2011), kartograficznym (Lisek, Nieścioruk 2015), bazodanowym (Szady 2016) czy turystycznym (Dye, Shaw 2007), a także w promowaniu turystyki regionalnej (Leszczyńska 2003) oraz w planowaniu, zarządzaniu i korzystaniu ze szlaków turystycznych (Jażdżewska i in. 2014).

Aplikacje GIS i mapy interaktywne, obejmujące swym zasięgiem przestrzennym cmentarze, są dostępne w mieście Marietta w stanie Georgia (USA) do prezentacji najstarszych zabytkowych nagrobków ${ }^{3}$, do nawigacji po dużych cmentarzach, np. największym kanadyjskim cmentarzu Notre-Dame-des-Neiges ${ }^{4}$ oraz Cmentarzu Powązkowskim w Warszawie, a także do poszukiwania miejsca pochówku weteranów i członków ich rodzin na cmentarzach amerykańskich rozproszonych w różnych miejscach kraju i będących pod opieką różnych instytucji, pod warunkiem, że grób oznaczony jest rządowym znacznikiem grobowym ${ }^{5}$. Projekt ten powstał dzięki współpracy Departamentu Weteranów USA z rządowym programem „Heritage Documentation Programs”, w ramach którego pracownicy Historic American Landscapes Survey (HALS) oraz Cultural Resources Geographic Information Systems (CRGIS) wspólnie stworzyli bazę danych pochówku weteranów, a następnie ich dokumentację i aplikację. Jest ona na bieżąco uaktualniana.

Ważnym aspektem wykorzystania GIS w dziedzictwie kulturowym jest współpraca specjalistów z różnych dziedzin, a w szczególności takich, które mają wiedzę i umiejętności z zakresu geoinformacji, a także znają dobrze obiekty, które znajdą się na interaktywnej mapie prezentującej pewien zasób dziedzictwa kulturowego. Niekiedy potrzebne są też kompetentne osoby wykonujące inwentaryzację terenową, która ma na celu sprawdzenie stanu zabytku oraz określenie jego precyzyjnego zlokalizowania. Nie bez znaczenia jest też wiedza kartograficzna redaktorów mapy, na problemy z redaktorami map cyfrowych zwracano nieraz uwagę, głównie poruszano kwestię tworzenia map przez informatyków - grafików, którzy nie znają metod i terminologii kartograficznej, a ich efekty trudno nazwać mapami (Jażdżewska 2010a; Kowalczyk 2018).

\footnotetext{
${ }^{3}$ https://www.esri.com/esri-news/arcnews/summer16articles/arcgis-keeps-past-alive-in-municipal-cemetery.

${ }^{4}$ https://www.esri.com/news/arcuser/0609/gisrip.html.

${ }^{5} \mathrm{https} / / /$ www.va.gov/landing_organizations.htm.
} 
Celem artykułu jest przedstawienie procesu tworzenia oraz pracy wynikowej w postaci mapy interaktywnej stworzonej wspólnie przez miłośników Starego Cmentarza w Łodzi oraz specjalistów geoinformacji Uniwersytetu Łódzkiego, którzy postanowili wykorzystać swoją wiedzę i umiejętności do upowszechnienia informacji o znamienitych postaciach pochowanych na Starym Cmentarzu w Łodzi. Inspiracją do podjęcia tego projektu był program realizowany przez Muzeum Miasta Łodzi w 2018 roku pt. „Łódzkie Oblicza Niepodległej” nawiązujący do obchodów rocznicy odzyskania przez Polskę niepodległości, do którego pracownicy Wydziału Nauk Geograficznych UŁ zostali zaproszeni. Autorki dziękują Panu Cezaremu Pawlakowi prezesowi Towarzystwa Opieki nad Starym Cmentarzem w Łodzi za okazaną pomoc i współpracę.

\section{Obszar badań - Stary Cmentarz w Lodzi}

Stary Cmentarz przy ulicy Ogrodowej w Łodzi jest jedną z najważniejszych oraz najbardziej cennych nekropolii w mieście (Czulda 2014), a także jedną z ciekawszych spośród nekropolii powstałych z końcem XIX i na początku XX wieku w Europie (Dominikowski 2004). Wśród najbardziej wartościowych polskich cmentarzy Stary Cmentarz w Łodzi znajduje się na wysokim miejscu - tuż po warszawskich Powązkach oraz krakowskich Rakowicach. Jego wyjątkowość w skali nie tylko miasta czy kraju, ale również Europy podkreśla trójwyznaniowy charakter (Czulda 2014). Pochowani są na nim katolicy, protestanci i prawosławni mieszkańcy miasta.

Dzieje cmentarza są ściśle związane z rozwojem przemysłowym Łodzi, gdzie od początków XIX wieku dynamicznie zmieniała się sytuacja demograficzna, dzięki masowo napływającej ludności z Polski oraz innych krajów z Europy. W ciągu krótkiego czasu Łódź stała się miastem wielonarodowościowym, wielowyznaniowym oraz wielokulturowym. Wielowyznaniowość uwidoczniła się w krajobrazie architektonicznym miasta, w szczególności w architekturze sakralnej (Pawlak 2009). W ówczesnych czasach w Łodzi mieszkała ludność czterech wyznań i kultur: polskiej, niemieckiej, rosyjskiej oraz żydowskiej. Pierwszy osobny cmentarz dla ludności żydowskiej mieścił się przy ul. Wesołej, a następny od 1892 roku przy ul. Brackiej. Przed utworzeniem Starego Cmentarza w Łodzi istniały dwa cmentarze katolickie. Najstarszy znajdował się przy drewnianym kościele katolickim pw. Wniebowzięcia Najświętszej Maryi Panny na terenie dzisiejszego placu Kościelnego. Obecnie nie ma tam cmentarza, a drewniany kościółek został przeniesiony w inne miejsce, ustępując murowanej świątyni pw. Wniebowzięcia Najświętszej Maryi Panny. Drugi cmentarz mieścił się przy drodze Retkińskiej, jednak w wyniku przepełnienia został zlikwidowany w 1856 roku i ekshumowany. Na teren zamkniętego cmentarza przeniesiono dawny drewniany kościółek, któremu nadano nowe wezwanie św. Józefa. Stary Cmentarz przy ul. Ogrodowej 
powstał jako trzeci w 1854 roku. Uroczyste poświęcenie odbyło się 9 września 1855 roku, a oficjalne zatwierdzenie jego powstania odbyło się dopiero w roku 1858. Cmentarz ulokowano poza granicami ówczesnego miasta, na terenach odkupionych od prywatnych właścicieli. Nowo powstały cmentarz zajmował powierzchnię bliską 9 hektarów. To, co było szczególnie ciekawe i unikatowe na tamte czasy w Polsce, ale i również w Europie, to fakt powstania wspólnego cmentarza dla trzech wyznań. Każda część wyznaniowa była odgrodzona od siebie niskim, żelaznym płotem. Cmentarz został otoczony ceglanym murem na przełomie lat 70. i 80., kiedy go powiększono do prawie 15 hektarów. Wtedy także zbudowano trzy bramy prowadzące do każdej z części. Czwarta brama została wzniesiona w 1888 roku przed aleją prowadzącą do kaplicy Scheiblerów. Prawdopodobnie po I wojnie światowej oddzielono żelbetowym murem część katolicką od prawosławnej i ewangelickiej. W 1895 roku dokonano ostatniego powiększenia cmentarza, który do chwili obecnej liczy 21 hektarów: 11 hektarów - część katolicka, 1 hektar - część prawosławna, 9 hektarów - część ewangelicka (Czulda 2014).

Stary Cmentarz przy ulicy Ogrodowej w Łodzi, podobnie jak Powązki w Warszawie można zaliczyć do cmentarzy o krajobrazie umownie ustalonego typu Père-Lachaise. Tego typu cmentarze czerpały wzorce $\mathrm{z}$ francuskiego pierwowzoru - Cimetière du Père-Lachaise, który został założony w 1803 roku na terenach kupionych przez władze Paryża. Typ Père-Lachaise cechuje się krajobrazem wysokiego i cienistego parku. Zgodnie z założeniami, teren takiego cmentarza jest podzielony szerokimi alejami, które wysadzane są drzewami wysokopiennymi i szybko rosnącymi, m.in.: klonami, dębami, kasztanowcami, wiązami, grabami, bukami i lipami. Typ ten charakteryzuje się również regularnymi kwaterami, które są luźno wypełniane artystycznymi pomnikami, zespołami architektoniczno-przestrzennymi oraz architektoniczno-rzeźbiarskimi, a także kaplicami grobowymi i mauzoleami. W polach grobowych zasadzana jest niska roślinność, głównie drzewa i krzewy iglaste. W krajobrazie Starego Cmentarza w Lodzi odnaleźć można również elementy krajobrazu cmentarzy zachodnich, głównie niemieckich $i$ austriackich. Są to kute ogrodzenia pól grobowych w postaci artystycznych krat i balustrad (Dominikowski 2004). Stary Cmentarz dzięki bogactwu form i stylistyki różnych pomników nagrobnych jest szczególnym miejscem o znaczeniu historycznym i zabytkowym. Znaczenie to podkreślają zabytki cenne nie tylko w skali kraju, ale czasami również Europy - około tysiąca kaplic grobowych, pomników nagrobnych, rzeźb czy ogrodzeń. Autorami tych dzieł są nierzadko wielkiej sławy architekci i rzeźbiarze oraz renomowani wykonawcy. Jest to miejsce pochówku wielu zasłużonych obywateli miasta, elity kulturalnej, finansowej i politycznej. Dodatkowe znaczenie historyczne dodają postacie związane z różnymi, ważnymi wydarzeniami z historii Polski: powstańcy listopadowi i styczniowi, żołnierze walczący o odzyskanie przez Polskę niepodległości w 1918 roku i jej obronę w latach 1920 i 1939-1945 (Pawlak 2009). 
Stary Cmentarz przy ulicy Ogrodowej jest miejscem wyjątkowym na mapie Łodzi. Jest to nekropolia, która w sposób szczególny opowiada o historii miasta i Polski, o życiu i losie mieszkańców. Jest dla wielu pokoleń świadectwem patriotyzmu, poświęcenia, odwagi, walki, zasług i wiedzy pochowanych tam ludzi. Niestety stan poszczególnych części cmentarza, pomników nagrobnych oraz innych elementów jego krajobrazu jest różny. Ważne jest podejmowanie działań pomagających ocalić od zapomnienia wielu spoczywających tam ludzi oraz cennych architektonicznie, artystycznie i historycznie zabytków (Czulda 2014).

\section{Mapy cyfrowe}

Powszechnym sposobem opisu przestrzeni są mapy. Najbardziej popularne i znane są mapy papierowe. W dzisiejszych czasach do opisu przestrzeni coraz częściej wykorzystuje się Systemy Informacji Geograficznej, które umożliwiają zbieranie oraz analizowanie danych z różnych dziedzin życia, a także ich wizualizacje (Gotlib, Iwaniak, Olszewski 2007). Postęp technologiczny, rozwój Internetu i rozwiązań cyfrowych wymusił wprowadzenie zmian w wielu dziedzinach, również w kartografii. Największe zmiany dotyczą zakresu oraz sposobu używania map - coraz częściej korzysta się z map publikowanych w Internecie. Mapy cyfrowe i aplikacje zyskują coraz większą popularność głównie ze względu na łatwą dostępność, a także atrakcyjność i różnorodność przekazu (Kowalski 2012).Według J. Gaździckiego (2001: 49), mapa cyfrowa to „model rzeczywistości geograficznej przedstawiony w postaci cyfrowej i przystosowany do komputerowego przetwarzania danych geograficznych oraz generowania map analogowych określonego obszaru".

Mapy udostępniane przez Internet można podzielić na mapy ilustracyjne, nazywane też statycznymi oraz mapy funkcyjne, inaczej interaktywne. Użyteczność obu typów map ocenia się głównie poprzez analizę treści kartograficznej, zmiennych graficznych, metody prezentacji kartograficznej, legendy oraz innych elementów pomocniczych. W przypadku map interaktywnych dodatkowo ocenia się elementy osnowy funkcyjnej. Mapy statyczne (ilustracyjne) są najprostszym, a także najczęstszym sposobem prezentowania materiałów kartograficznych w Internecie (Kowalski 2012). Za tego typu mapę uznaje się plik rastrowy, publikowany głównie w formacie jpeg lub png, wyświetlający mapę zamieszczoną na stronie internetowej (Longley, Goodchild, Maguire, Rhind 2006). Takie mapy tworzone są przede wszystkim w celach lokalizacyjnych, informacyjnych i marketingowych (Kowalski 2000). Mapa interaktywna jest aplikacją sieciową, która wyświetla treść kartograficzną. Zazwyczaj jest to mapa wektorowa z poszczególnymi elementami, w której interfejs użytkownika, na który składają się panel warstw informacyjnych, paski narzędziowe, narzędzia sterujące, legenda czy etykiety tekstowe, umożliwia wykonywanie różnych operacji (przybliżanie, oddalanie, 
przesuwanie, wyświetlanie informacji tekstowych, zdjęć, filmów, zewnętrznych odnośników). Jest to mapa wykonana za pomocą różnych technologii, np. w postaci geoportalu (Kubik 2009). Ważną funkcję na mapie interaktywnej pełni legenda, gdzie jest ściśle związana z obrazem mapy, bardziej niż na tradycyjnych mapach papierowych, na których jest umieszczona w oddzielnym miejscu kompozycji mapy (Kowalski 2012).

Obecnie mapy cyfrowe zyskują na popularności. Na stronach internetowych o różnej tematyce znaleźć można wiele map cyfrowych zarówno prostych, statycznych, jak również bardziej zaawansowanych map interaktywnych. Mapy publikowane $\mathrm{w}$ Internecie różni nie tylko prezentowana tematyka, ale również technologia wykonania oraz funkcjonalność (Jasion 2018).

\section{Metody i źródła danych}

Koncepcja utworzenia interaktywnej mapy Starego Cmentarza w Łodzi powstała - jak wspomniano wcześniej - dzięki współpracy przedstawicieli różnych dyscyplin i z tego powodu metody naukowe wykorzystywane w pracy też pochodzą z różnych dyscyplin: historii, geografii społeczno-ekonomicznej i GIScience. Ostatnia z nich nie jest jeszcze oficjalnie uznaną dyscypliną w Polsce, ale w innych krajach - przede wszystkim w USA - jest ona już obecna od kilkunastu lat. W niniejszej pracy jest ona o tyle ważna, że integruje pozostałe, a specjaliści geoinformacji musieli „czuwać” na każdym etapie badań nad tym, aby zebrane dane mogły być wykorzystane w końcowym efekcie pracy. W artykule zostaną omówione metody wykorzystywane przez specjalistów geoinformacji. Można je podzielić na kilka części: pozyskanie danych, ich przetworzenie i integracja, zaprojektowanie i tworzenie bazy danych, wybór narzędzia informatycznego do stworzenia interaktywnej mapy, koncepcja prezentacji danych i ich wizualizacja, a na koniec ich popularyzacja.

Dane niezbędne do opracowania interaktywnej mapy Starego Cmentarza w Łodzi pochodziły z różnych źródeł i były opracowywane przez specjalistów różnych dyscyplin. Muzeum Miasta Łodzi udostępniło archiwalne źródła pisane, materiały kartograficzne, ikonograficzne w postaci cyfrowej w formacie plików JPG oraz opisy postaci w dokumentach tekstowych MS Word. Informacje o lokalizacji poszczególnych nagrobków były zbierane na terenie Starego Cmentarza kilkukrotnie. Jednym z pierwszych działań zmierzających do powstania interaktywnej mapy Starego Cmentarza w Łodzi były zajęcia inwentaryzacyjne na Starym Cmentarzu, które odbyły się 24 maja 2018 roku. Grupą, która miała za zadanie dokonanie inwentaryzacji wyznaczonych pomników nagrobnych byli studenci I roku gospodarki przestrzennej Politechniki Łódzkiej. Studenci, podzieleni na grupy, wraz z opiekunami poszczególnych grup, którymi byli członkowie Towarzystwa Opieki nad Starym Cmentarzem w Łodzi, pracownicy Muzeum 
Miasta Łodzi, przedstawiciele Zakładu Geoinformacji Uniwersytetu Łódzkiego. Studenci Politechniki Łódzkiej mieli do dyspozycji karty inwentaryzacyjne w wersji papierowej oraz elektronicznej w formularzu Google, do których wprowadzali informacje o cechach pomników nagrobnych oraz informacje dotyczące pochowanych tam osób. Przy opracowaniu interaktywnej mapy, najważniejszą częścią pracy studentów było sprawdzenie lokalizacji pomników nagrobnych i zaznaczenie ich w formie punktów w aplikacji Google MyMaps na własnych smartfonach. Punkty zebrane przez studentów zostały wczytane do programu ArcGIS i połączone w jedną warstwę. Punkty oraz ich atrybuty wymagały również odpowiedniego uporządkowania i ujednolicenia. Sprawdzono kompletność i poprawność zebranych danych. Konieczne okazało się kolejne spotkanie inwentaryzacyjne na Starym Cmentarzu w Łodzi, którego celem było sprawdzenie poprawności lokalizacji części punktów oraz zaznaczenie kilku brakujących pomników nagrobnych, które nie zostały uwzględnione przez studentów. Spotkanie to odbyło się w mniejszym gronie z udziałem przedstawicieli Zakładu Geoinformacji oraz koordynatora projektu Pana Cezarego Pawlaka. Następnie dodano brakujące punkty do poprzednio utworzonej warstwy. Łącznie zebrano i poprawiono 62 punkty z lokalizacją pomników nagrobnych ujętych w opracowaniu (ryc. 1).

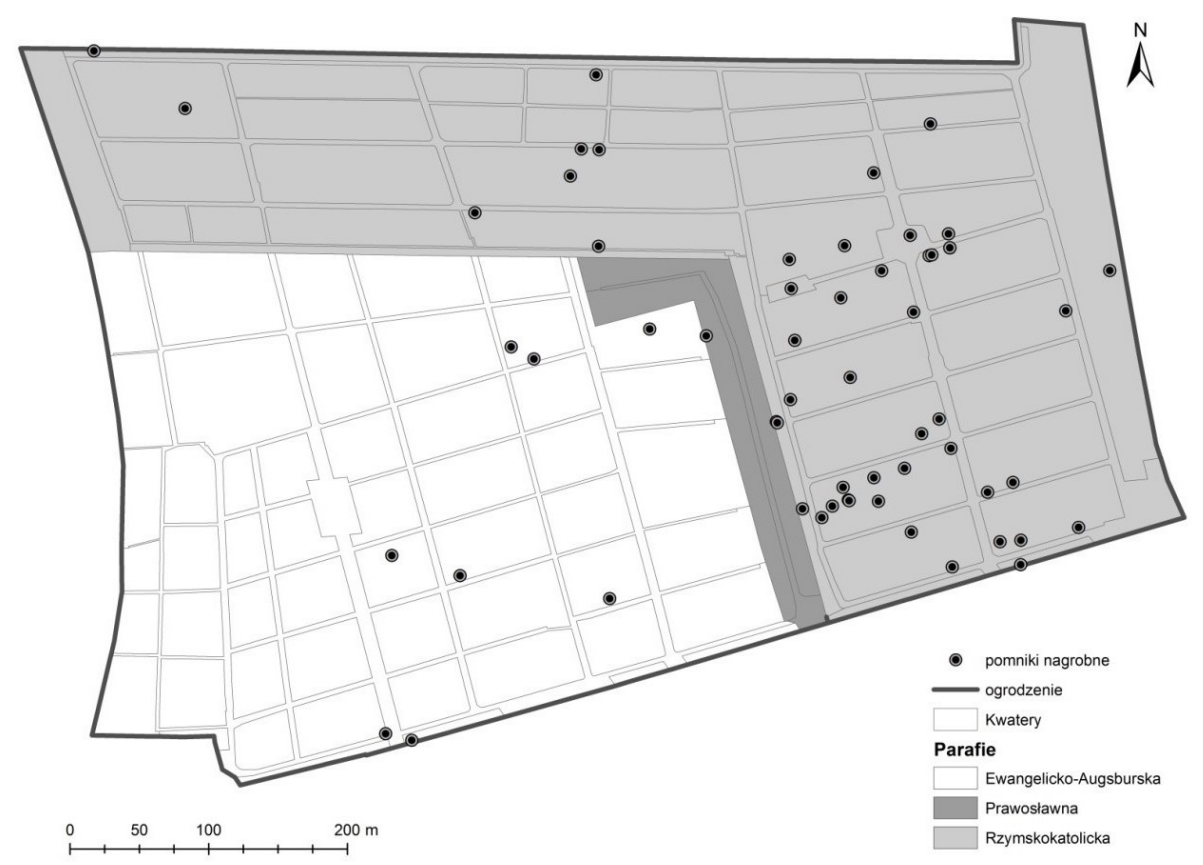

Ryc. 1. Rozmieszczenie pomników nagrobnych ujętych przy opracowaniu interaktywnej mapy Starego Cmentarza w Łodzi

Źródło: opracowanie własne. 
Postaci i ich nagrobki wybrane do prezentacji na mapie zostały przyporządkowane do pięciu rozdziałów tematycznych, z którymi związane było ich życie, wykonywana praca, działalności i pasje, były to:

- Aktywny opór. Powstańcy i rewolucjoniści epoki zaborów;

- Żołnierze Niepodległej. Na drodze do wolności 1914-1920;

- Praca u podstaw. Działacze społeczni do 1939 roku;

- W służbie miastu i krajowi. Samorządowcy i politycy w latach II Rzeczypospolitej;

- Obrońcy niepodległej. Żołnierze i konspiratorzy na frontach II wojny światowej. Wyszczególnieniem rozdziałów oraz przypisaniem do nich określonych osób zajął się zespół pracowników Muzeum Miasta Łodzi. Do opracowania interaktywnej mapy niezbędne było stworzenie bazy danych. Zadaniem specjalistów geoinformacji było jej skonstruowanie w taki sposób, aby powstałe punkty uwzględniały numerację rozdziałów oraz dały się jasno powiązać z informacjami opisowymi i fotografiami. Baza danych składała się z czterech kolumn: specjalnie utworzonego numeru identyfikacyjnego osoby, jej imienia i nazwiska, numeru rozdziału oraz numeru kolejności przedstawienia na mapie. Liczbę osób znajdujących się w każdym z rozdziałów przedstawia tabela 1 .

Tabela 1. Liczba osób należących do poszczególnych rozdziałów

\begin{tabular}{lc}
\hline \multicolumn{1}{c}{ Nazwa rozdziału } & Liczba osób \\
\hline Aktywny opór. Powstańcy i rewolucjoniści epoki zaborów & 9 \\
\hline Żołnierze Niepodległej. Na drodze do wolności 1914-1920 & 14 \\
\hline Praca u podstaw. Działacze społeczni do 1939 roku & 15 \\
\hline $\begin{array}{l}\text { W służbie miastu i krajowi. Samorządowcy i politycy w latach } \\
\text { II Rzeczypospolitej }\end{array}$ & 11 \\
\hline $\begin{array}{l}\text { Obrońcy niepodległej. Żołnierze i konspiratorzy na frontach } \\
\text { II wojny światowej }\end{array}$ & 13 \\
\hline
\end{tabular}

Źródło: opracowanie własne.

Mapa interaktywna powinna być użyteczna i funkcjonalna, a jej redakcja jest zadaniem trudnym (Opach 2008), gdyż wymaga wiedzy i metod informatycznych oraz kartograficznych (Kowalski 2012). Za wykonanie interaktywnej mapy Starego Cmentarza w Łodzi odpowiedzialni byli: mgr Łukasz Lechowski i mgr Angelika Jasion z Zakładu Geoinformacji Wydziału Nauk Geograficznych Uniwersytetu Łódzkiego, którzy postanowili, że do jej stworzenia wykorzystana zostanie platforma ArcGIS Online. Jest to aplikacja stworzona przez firmę ESRI, działająca w chmurze i służąca do tworzenia map i analiz. W opracowaniu wykorzystano szablon projektu ArcGIS Online-Story Map Journal. Jest to szablon, który 
pozwala na połączenie mapy wraz z opisami tekstowymi i zdjęciami w atrakcyjny i przejrzysty sposób. Map Journal, co możemy przetłumaczyć jako pewnego rodzaju dziennik map, podzielony jest na przewijalne sekcje, które mogą tworzyć rozdziały całego zagadnienia. Szablon ten składa się z dwóch części: obszaru głównego oraz panelu bocznego lub panelu przestawnego. Obszar główny przeznaczony jest przede wszystkim do prezentacji map, natomiast panel boczny lub przestawny służy głównie do publikacji tekstów, obrazów i filmów. Możliwe jest dokonanie zmiany wyglądu aplikacji poprzez zmianę jej układu, kolorów, czcionki czy dodanie własnego loga. Ważnym elementem szablonu jest możliwość dodawania sekcji, które stanowią rozdziały określonej pracy oraz dostosowania aplikacji do ich wyświetlania na przykład tak, aby podczas przewijania zawartości panelu bocznego przełączane były nowe mapy przedstawiające prezentowane treści lub żeby mapa była automatycznie przesuwana i przeskalowywana do punktów, które są aktualnie prezentowane. W trakcie pracy nad aplikacją możemy dokonywać jej wielokrotnych edycji. Ostatnim etapem pracy jest udostępnienie mapy wszystkim użytkownikom bądź określonym grupom, w zależności od rodzaju posiadanego konta.

\section{Wyniki}

Interaktywna mapa Starego Cmentarza w Łodzi pt. „Łódzkie Oblicza Niepodległej" została wykonana, jak już wspomniano, na platformie ArcGIS Online na podstawie szablonu projektu Story Map Journal. Obszar główny szablonu zawiera mapę Starego Cmentarza w Łodzi składającą się z trzech warstw:

- pomników nagrobnych osób uwzględnionych w projekcie (punktowa);

- podziału cmentarza na kwatery (poligonowa);

- podziału cmentarza na trzy parafie (poligonowa).

Mapa przedstawiona jest na podkładzie OpenStreetMap (ryc. 2), można ją przesuwać, a także zmieniać jej skalę. Panel boczny składa się z głównej sekcji stanowiącej wstęp oraz nawigację do określonych rozdziałów, a także kolejnych pięciu sekcji tożsamych z prezentowanym rozdziałem i przedstawiających informacje o poszczególnych osobach. Zaproponowane rozdziały stanowią w pewien sposób propozycję tras przewodnika po Starym Cmentarzu (ryc. 2).

Do oznaczenia lokalizacji pomników nagrobnych użyto prostej sygnatury punktowej, której kolor jest przyporządkowany do określonego rozdziału. Z kolei metodę chorochromatyczną zastosowano do oznaczenia granic parafii różnych wyznań. Pozwala to użytkownikowi mapy odczytać nie tylko położenie obiektu, ale również wyznanie osoby pochowanej w tym miejscu. Kwatery są obiektami powierzchniowymi, dlatego uznano, że ich zasięg najkorzystniej będzie

\footnotetext{
${ }^{6}$ https://ul-wng.maps.arcgis.com/apps/MapJournal/index.html?appid=ca468bcf7a084 043a657384e164afb00.
} 
oddany w postaci zarysu granic z przezroczystym wypełnieniem, aby nie zasłaniać przynależności do parafii. Legenda, w której znajdują się opisy elementów mapy jest rozwijalna i znajduje się po jej prawej stronie (ryc. 3).

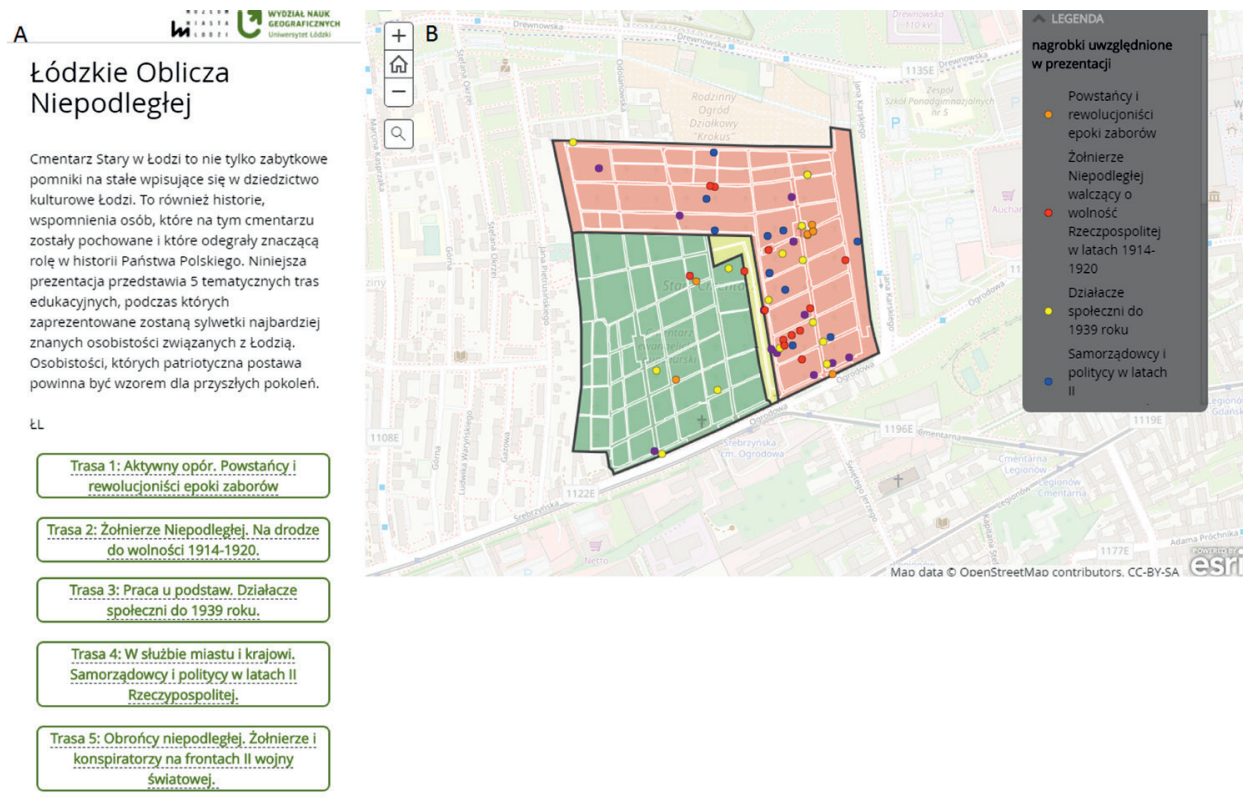

Ryc. 2. Panel boczny (A) oraz obszar główny (B) interaktywnej mapy Starego Cmentarza w Łodzi

Źródło: opracowanie własne.
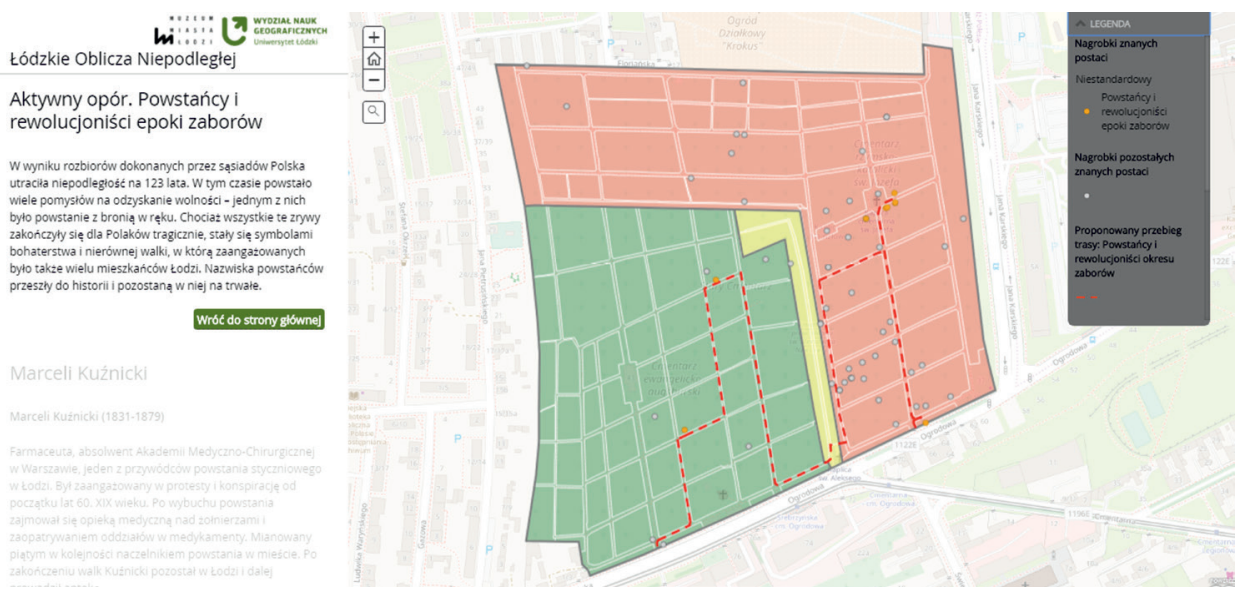

Ryc. 3. Widok ogólny trasy

Źródło: opracowanie własne. 
Po zaznaczeniu wybranej trasy, aplikacja przenosi użytkownika do widoku, który składa się również z dwóch części: panelu bocznego i obszaru głównego mapy (ryc. 3). W tym momencie aplikacja prezentuje w obszarze głównym mapę z propozycją trasy spaceru, na której wyszczególnione są innym kolorem pomniki nagrobne osób związanych z określonym tematem trasy, a także z odpowiednio dostosowaną legendą. W panelu bocznym użytkownik znajdzie tytuł proponowanej trasy oraz jej krótką charakterystykę; dodatkowo umieszczony jest link umożliwiający powrót do pierwszej strony nawigacyjnej.

Przewijając panel boczny w dół, aplikacja prowadzi użytkownika zgodnie z wyznaczonym szlakiem po wszystkich należących do niego nagrobkach. W czasie przewijania panelu bocznego, wyświetlane są informacje tekstowe oraz zdjęcia i inne obrazy dotyczące poszczególnych postaci, a obszar główny mapy jest przeskalowywany (powiększany) i przesuwany do pomnika nagrobnego opisywanej osoby (w tym momencie odpowiednia sygnatura na mapie powiększa się). Dla zainteresowanych użytkowników, oprócz krótkiego opisu tekstowego oraz materiałów ikonograficznych dotyczących określonej postaci, umieszczono także link umożliwiający dostęp do bardziej szczegółowych informacji opracowanych przez pracowników muzeum (ryc. 4).

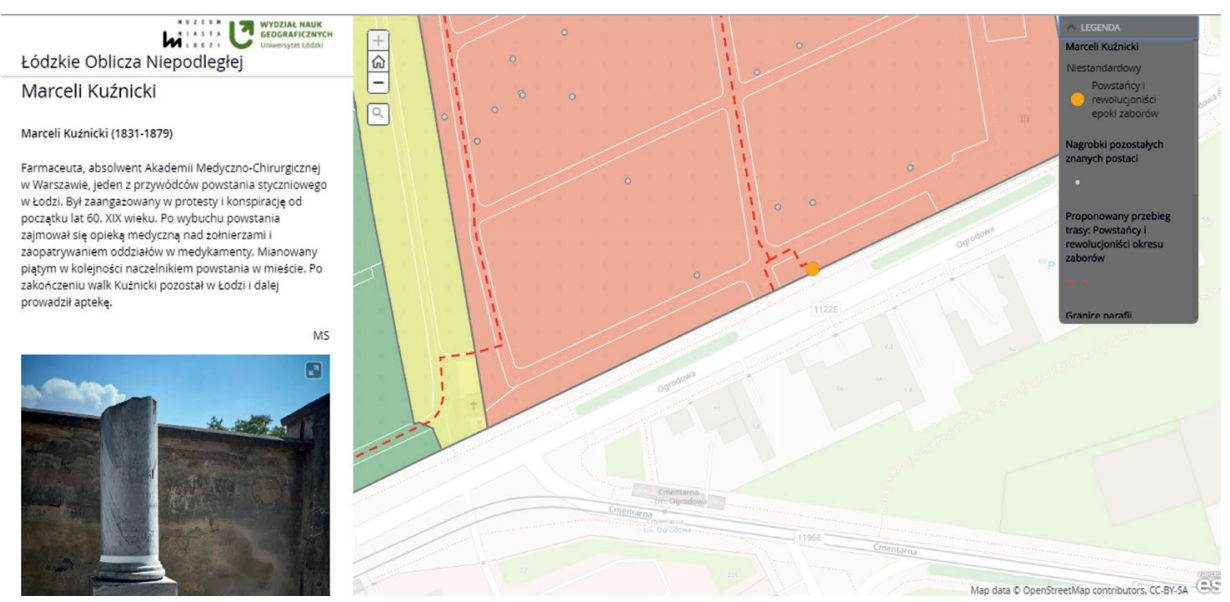

Ryc. 4. Widok po przejściu do określonej postaci na trasie

Źródło: opracowanie własne.

Warto zaznaczyć również, że powstała mapa interaktywna jest aplikacją responsywną, co pozwala na korzystanie z niej nie tylko na komputerach, ale również na innych urządzeniach typu tablet czy smartfon z pełną funkcjonalnością i specjalnie dostosowanym widokiem (ryc. 5). Dzięki temu jej walor edukacyjny jest jeszcze większy, gdyż można wcześniej zapoznać się z koncepcją mapy, jej treścią i możliwościami, a następnie zaplanować spacer po Starym Cmentarzu i skorzystać z niej po raz kolejny z urządzeniem mobilnym. 

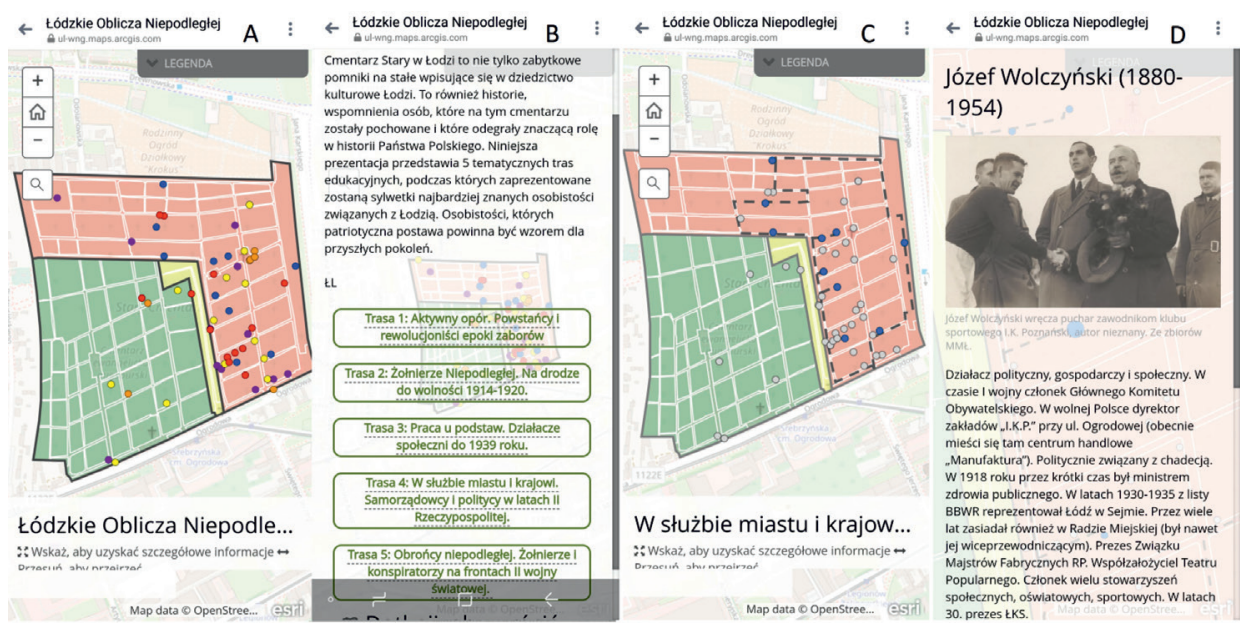

Ryc. 5. Widok aplikacji w wersji mobilnej - widok główny (A), panel boczny z częścią nawigacyjną (B), widok określonej trasy (C), wyświetlanie przykładowej postaci (D)

Źródło: opracowanie własne.

\section{Wnioski}

Wykorzystanie GIS w dziedzictwie kulturowym opiera się na współpracy specjalistów z różnych dziedzin, głównie specjalistów geoinformacji oraz dziedzictwa kulturowego $\mathrm{w}$ zakresie tematycznym mapy. W tym przypadku, w określonych etapach przygotowania aplikacji, brali udział: pracownicy Muzeum Miasta Łodzi, członkowie Towarzystwa Opieki nad Starym Cmentarzem w Lodzi, studenci Politechniki Łódzkiej oraz pracownicy Zakładu Geoinformacji Wydziału Nauk Geograficznych Uniwersytetu Łódzkiego. Poszczególne zespoły pracowały nad różnymi etapami prac od stworzenia koncepcji powstania mapy interaktywnej, przez zbiór danych zarówno przestrzennych, jak i aprzestrzennych po ich przetworzenie i opracowanie w postaci aplikacji ArcGIS Online. W niniejszym projekcie współpraca była bardzo dobra, dzięki osobom bezpośrednio zaangażowanym w ten projekt, który powstał w ciągu pół roku. Takie przedsięwzięcie wymaga dużych nakładów pracy, czasu oraz zainteresowania i troski, a także, co bardzo ważne, koordynacji i wzajemnego zrozumienia. Wszystkie działania muszą być przemyślane i skonsultowane z pozostałymi członkami projektu. Niezwykle istotne jest, aby mapa interaktywna służyła osobom zainteresowanym przez wiele lat. Z tego powodu powinna być ona pod opieką instytucjonalną jednej z grup, która uczestniczyła w jej przygotowaniu, w tym przypadku jest to Zakład Geoinformacji Wydziału Nauk Geograficznych Uniwersytetu Łódzkiego oraz Muzeum Miasta Łodzi. 
Powstała interaktywna mapa Starego Cmentarza w Łodzi pt. „Łódzkie Oblicza Niepodległej" jest propozycją wirtualnej wycieczki po Starym Cmentarzu oraz zachętą do odwiedzenia nekropolii i bezpośredniego kontaktu z opisywanymi nagrobkami, przez co ma duży walor edukacyjny. Jest atrakcyjną formą przekazu informacji o wybitnych postaciach pochowanych na Starym Cmentarzu w Łodzi - łączy mapy, informacje tekstowe i obrazy. Istnieje możliwość ich aktualizacji oraz dodawania nowych danych i funkcji.

Interaktywna mapa Starego Cmentarza w Łodzi została zaprezentowana podczas corocznego święta użytkowników i twórców Systemów Informacji Geograficznej GISday 2018, który miał miejsce 14 listopada na Wydziale Nauk Geograficznych Uniwersytetu Łódzkiego oraz podczas gali podsumowującej całoroczny cykl wydarzeń w ramach projektu „Łódzkie Oblicza Niepodległej”, która odbyła się 18 listopada 2018 roku w Muzeum Miasta Łodzi. Mapa będzie dalej promowana wśród mieszkańców i turystów, gdyż jej walor edukacyjny jest niewątpliwy.

\section{Literatura}

Czulda A.B., 2014, Za kurtyna pamięci. Trójwyznaniowy Cmentarz Stary w Łodzi, Muzeum Kinematografii w Łodzi, Łódź.

Dominikowski J., 2004, Nekropolia Łodzi wielkoprzemysłowej. Cmentarz Stary przy ulicy Ogrodowej. Dzieje i sztuka 1854-1945, Wydawnictwo Konserwatorów Dzieł Sztuki, Łódź.

Dye A.S., Shaw S.-L., 2007, A GIS-based spatial decision support system for tourists of Great Smoky Mountains National Park, ,Journal of Retailing and Consumer Services", 14: 269-278.

Gaździcki J., 2001, Leksykon geomatyczny, Wieś Jutra, Warszawa.

Gotlib D., Iwaniak A., Olszewski R., 2007, GIS: obszary zastosowań, Wydawnictwo Naukowe PWN, Warszawa.

Gregory I., 2003, A place in history: A guide to using GIS in historical research, [w:] Arts and Humanites Data Service, Oxbow, Oxford.

International Journal of Humanities and Arts Computing, 2009, Edinburgh University Press for the Association for History and Computing.

Jasion A., 2018, Wykorzystanie cyfrowej mapy turystycznej do wspierania rozwoju turystyki na obszarach wiejskich na przykładzie gmin wiejskich województwa łódzkiego, „Acta Universitatis Lodziensis. Folia Geographica Socio-Oeconomica”, 31: 103-119.

Jażdżewska I., 2010a, Recenzja mapy Ziemia Łódzka, Autor mapy: Piotr Wypych, [w:] Największe atrakcje turystyczne Łodzi i regionu łódzkiego, „Polski Przegląd Kartograficzny", 42: 50-52.

Jażdżewska I., 2010b, Zastosowanie Systemów Informacji Geograficznej (GIS) w zachowaniu dziedzictwa kulturowego, [w:] Więcek B., Perkowski J. (red.), Rola nauki w zachowaniu dziedzictwa kulturowego: wspótpraca między uczelniami wyższymi a muzeami, archiwami $i$ stużbami konserwatorskimi na terenie regionu tódzkiego, Wydawnictwo Politechniki Łódzkiej, Łódź: 167-183. 
Jażdżewska I., Kaleniewicz A., Maroszek M., Piotrowski K., Rogowski M., 2014, Nowoczesne technologie w planowaniu, zarządzaniu i korzystaniu ze szlaków turystycznych, [w:] Stasiak A., Śledzińska J., Włodarczyk B. (red.), Szlaki turystyczne od pomystu do realizacji, Wydawnictwo PTTK Kraj: 649-669.

Kemp K.K., 2009, What can GIS offer history?, „International Journal of Humanities and Arts Computing", 3: 15-19.

Kowalczyk A., 2018, Wykorzystanie metod kartografii i geowizualizacji w turystyce kulturowej, ,Turystyka Kulturowa”, 5: 80-106.

Kowalski P.J., 2000, Polska kartografia w Internecie, [w:] Kartografia polska u progu XXI wieku, XXVII Ogólnopolska Konferencja Kartograficzna, Główny Urząd Geodezji i Kartografii, Warszawa: 265-289.

Kowalski P.J., 2012, Mapa jako praktyczny interfejs serwisu internetowego, „Archiwum Fotogrametrii, Kartografii i Teledetekcji”, 23: 159-168.

Kubik T., 2009, GIS - rozwiazania sieciowe, Wydawnictwo Naukowe PWN, Warszawa.

Kulesza M., 2003, Krajobraz kulturowy województwa tódzkiego - mity i rzeczywistość, [w:] Orłowska E., Klementowski J. (red.), Kulturowy aspekt badań geograficznych. Studia teoretyczne i regionalne, Polskie Towarzystwo Geograficzne o/Wrocław, Instytut Geografii i Rozwoju Regionalnego, Uniwersytet Wrocławski, Wrocław: 75-83.

Lechowski Ł., 2011, Dziedzictwo kulturowe przemystu elektromaszynowego w Łodzi. Charakterystyka przestrzenna z wykorzystaniem narzędzi GIS, „Acta Universitatis Lodziensis. Folia Geographica Socio-Oeconomica", 11: 219-239.

Leszczyńska M., 2003, Rola GIS w promowaniu turystyki regionalnej, „Archiwum Fotogrametrii, Kartografii i Teledetekcji”, 13: 129-133.

Lisek K., Nieścioruk K., 2015, The cartographic methods of presentation and GIS tool in analysis of historical data on the example of Great War cemeteries in southern Poland, „Polish Cartographical Review”, 47: 225-239.

Longley P.A., Goodchild M.F., Maguire D.J., Rhind D.W., 2006, GIS. Teoria i praktyka, Wydawnictwo Naukowe PWN, Warszawa.

Lorenc-Karczewska A., Witkowski W., 2002, Dziedzictwo kulturowe. Parki krajobrazowe nie tylko zielone, czyli rzecz o dziedzictwie kulturowym, [w:] Kurowski J.K. (red.), Parki Krajobrazowe Polski Środkowej. Przewodnik sesji terenowych, Łódź.

Opach T., 2008, Internetowa „mała kartografia”, „Polski Przegląd Kartograficzny”, 40: $128-143$.

Pawlak C., 2009, Piękno ocalone. Stary Cmentarz przy ulicy Ogrodowej w Łodzi, Towarzystwo Opieki nad Starym Cmentarzem przy ulicy Ogrodowej w Łodzi, Łódź.

Szady B., 2016, Spatio-temporal databases as research tool in historical geography, „Geographia Polonica”, 89: 359-370.

\section{Źródła internetowe}

http://www.visionofbritain.org.uk.

https://ul-wng.maps.arcgis.com/apps/MapJournal/index.html?appid=ca468bcf7a084043a $657384 \mathrm{e} 164 \mathrm{afb} 00$.

https://www.esri.com/esri-news/arcnews/summer16articles/arcgis-keeps-past-alive-in-municipal-cemetery.

https://www.esri.com/news/arcuser/0609/gisrip.html.

https://www.va.gov/landing_organizations.htm. 


\title{
INTERACTIVE MAP OF THE OLD CEMETERY IN LODZ AS A RESULT OF INTERDISCIPLINARY COOPERATION BETWEEN DIFFERENT ENVIRONMENTS
}

\begin{abstract}
The Old Cemetery in Lodz is one of the few necropolis on which the followers of three Christian denominations were buried: Catholics, Protestants and Orthodox. It is an unquestionable tourist attraction of the city, and its sightseeing may have a well-considered character, eg. according to selected criteria or random in the form of a walk. People who go to this historic cemetery may have certain preferences as to visiting it in one day. Many well-known personalities were buried in the cemetery: science, culture, city self-government, soldiers, doctors, social activists and others. Thanks to the collected spatial information (location of the tombstone) and non-spatial information (biography, photographs), you can use the opportunities offered by Geographic Information Systems to support the decision of tourists. The article presents an app created jointly by fancies of the Old Cemetery in Lodz and geoinformation specialists who decided to help visitors to the Old Cemetery in Lodz. They can choose tombstones according to personal preferences and plan the tour route, as well as familiarize themselves with the biographies and photographs of people who were buried in this cemetery. It has educational value and city promotion.
\end{abstract}

Keywords: interactive map, Old Cemetery, Lodz, geoinformation, cultural heritage, GIS.

Dr hab. Iwona Jażdżewska, prof. UŁ

Mgr Angelika Jasion

Zakład Geoinformacji

Instytut Geografii Miast i Turyzmu

Wydział Nauk Geograficznych

Uniwersytet Łódzki

e-mail: iwona.jazdzewska@geo.uni.lodz.pl e-mail: angelikajasion@gmail.com 